\title{
Interleukin -18 and other inflammatory cytokines as independent predictors of diabetic nephropathy in patients with type 2 diabetes mellitus.
}

\author{
Sahar M.Shawky *; and Eman A. Ismail** \\ Internal Medicine* and Clinical Pathology ** Departments. \\ Faculty of Medicine, Ain Shams University
}

\begin{abstract}
Diabetes Mellitus is a very common cause of glomerular disease in adults and is a very common cause of end stage renal failure. The pathogenesis of diabetic nephropathy is not completely understood dispite extensive investigations. Involvement of the kidneys in patients with diabetes mellitus includes not only hyperglycemia, advanced glycosylation products but also activation of proinflammatory cytokines. Data about the relationship of inflammation to nephropathy in type 2 diabetes mellitus are scarce.

Our study was conducted to compare levels of interleukin - 18 ( IL- 18), tumor necrosis factor-alpha.( TNF- $\alpha$ ) and interleukin- 6 (IL-6) in serum of diabetic patients with various degrees of nephropathy. The study included 50 patients and 35 normal control subjects presented at Ain Shams University Hospitals. The diabetic subjects were divided into 3groups according to urinary albumin excretion ( UAE):

○ Group I : included 22 subjects with $\mathrm{UAE}<30 \mu \mathrm{g} / \mathrm{mg}$ creatinine i.e diabetic patients with normoalbuminuria.

○ Group II : included 20 subjects. with UAE 30 to $300 \mu \mathrm{g} / \mathrm{mg}$ creatinine i.e. diabetic patients with microalbuminuria .

○ Group III : Included 8 subjects with UAE > $300 \mu \mathrm{g} / \mathrm{mg}$ creatinine i.e. diabetic patients with macroalbuminuria.

The serum levels of IL-18, TNF- $\alpha$ and IL-6 were measured for the control group to determine the normal values and for all diabetic subjects with various degrees of nephropathy .

The results revealed highly significant statistical differences in serum levels of IL-18, TNF- $\alpha$ and IL- 6 between the patients and control subjects. In addition, IL-18 levels were increased in diabetic patients with proteinuria as compared with those without proteinuria. Also TNF- $\alpha$ and IL- 6 in diabetic patients with microalbuminuria and clinical albuminuria were significantly increased as compared with diabetic patients without albuminuria.

These results suggest that serum levels of IL-18, TNF- $\alpha$ and IL-6 may have etiopathogenic roles in diabetic nephropathy and are independent predictors of UAE in type 2 diabetes mellitus. So, in addition to metabolic and hemodynamic factors, it is possible to consider the participation of inflammation on the pathogenesis of diabetic nephropathy.
\end{abstract}

\section{Introduction}

Nephropathy is a major contributor to overall morbidity and mortality in diabetic patients( Dipetrillo et al., 2003 ).

Diabetic nephropathy is a clinical syndrome characterized by persistent albuminuria > $300 \mathrm{mg} /$ day, with a decline in glomerular filteration rate, and elevated arterial blood pressure ( Timothy et al., 2000 )

Diabetic nephropathy is one of the leading causes of chronic renal failure. Although both type I diabetes mellitus and type 2 diabetes mellitus lead to end stage renal disease, the great majority of patients 


\section{Interleukin -18 and other inflammatory cytokines}

are those with non insulin dependent diabetes mellitus ( Remuzzi et al., 2002 ) .

The exact cause of diabetic nephropathy is unknown but various postulated mechanisms are considered: hyperglycemia, advanced glycosyulation products and activation of cytokines ( Remuzzi et al., 2002).

Cytokines are small proteins or peptides that occur naturally in mammalian species and have multiple physiologic functions, including modulation of immune functions. For example; tumor necrosis factor alpha (TNF- $\alpha)$ which is a cytokine produced primarily by monocytes and macrophages, also known cachectin, activates macophages, stimulates polymorph nuclear chemotoxin, angiogenesis and are cytotoxic to many cells. It is involved in the production and maintenance of the inflammatory response (Bennatt, 1996 ).

TNF- $\alpha$ may have some etiopathogenic role in development of diabetic nephropathy since it is increased with the presence of albuminuria, and may also reflect early diabatic nephropathy since increased levels were observed in diabetic patients without overt proteinuria (Moriwaki et al., 2003 )

\section{Aim of the work}

The aim of this work is to detect the clinical significance of proinflammatory cytokines ( IL-18, TNF- $\alpha$, IL-6 ) in patients with type 2 diabetes mellitus and its relationship with diabetic nephropathy as regarding the urinary albumin excretion even in the absence of an elevated serum creatinine value.

\section{Subjects and methods}

This study was carried out on 50 patients with type 2 diabetes mellitus of various degrees of nephropathy. The patients presented at nephrology clinic, Ain- Shams hospital. Their ages ranged from 50 to 60 years with a mean value of $53.2 \pm 1.0$. Twenty- seven were males and 23 were females with a male to female ratio of 1.2: 1 .

Thirty-five age-and sex-matched healthy volunteers were enrolled in the present study as a control, 20 were males and 15 were females with male to female ratio of 1.3:1. Control subjects were judged normal after a physical examination, as well as standard hematological and biochemical evaluations.

Diagnosis of type 2 diabetes mellitus was based on the criteria of the American Diabetes Association (1997). Twenty seven of the patients were receiving insulin and 23 were receiving oral hypoglycemic drugs.

Patients with acute illness or taking drugs that might have had some effects on serum cytokine levels were excluded.

All the patients and controls were subjected to the following:

A- Detailed history and thorough clinical examination with special emphasis on age, sex, body mass index (BMI) and presence of macroangiopathy (old cerebral infarction, myocardial infarction and atherosclerosis obliterans ).

\section{B- Laboratory investigations:}

Fasting blood glucose (FBG), serum creatinine, blood urea, lipid profile, Creactive protein (CRP) and hemoglobin $\mathrm{Alc}$ (HbAlc) were estimated. Albumin excretions in spot urine samples, collected during outpatient clinic examinations, were estimated on at least 2 separate occasions and the patients were classified into 3 groups according to the definition of abnormalities in albumin excretion advocated by the American Diabetes Association (1998) with less than $30 \mathrm{ug} / \mathrm{mg}$ creatinine, 30 to $300 \mu \mathrm{g} / \mathrm{mg}$ creatinine, and greater than $300 \mu \mathrm{g} / \mathrm{mg}$ creatinine used to represent normal (normoalbuminuria), microalbuminuria, and clinical albuminuria, respectively.

Serum levels of IL-18, TNF- $\alpha$ and IL-6 were measured using a solid phase Sandwich enzyme - linked immunosorbent assay (ELISA) with the respective mouse monoclonal antibodies. Sandwich ELISA for measurement of IL-18, TNF- $\alpha$ and IL-6 was developed by the modified method described by (Park et al., 1993 ) . While concentrations of IL-18 in serum were measured with a human IL-18 ELISA kit (medical \& biological Laboratories, Nagoya, Japan), with a minimum detectable 
concentration of $12.5 \mathrm{pg} / \mathrm{ml}$. The intraassay coefficients of variation (CVs) of IL18 were between $4.9 \%$ ( at $600.7 \mathrm{pg} / \mathrm{ml}$ ) and $9.9 \%$ (at $69.7 \mathrm{pg} / \mathrm{ml}$ ), and the interassay CVs were from $5.2 \%$ ( at $615.1 \mathrm{pg} / \mathrm{ml}$ ) to $10.1 \%$ ( at $2621.1 \mathrm{pg} / \mathrm{ml}$ ) . Serum concentrations of TNF- $\alpha$ and IL-6 were measured with a BioSource immunoassay kit (BioSource international, Camarillo, CA). The minimum detectable concentrations of TNF- $\alpha$ and IL -6 were $3 \mathrm{pg} / \mathrm{ml}$ and $2 \mathrm{pg} / \mathrm{ml}$, respectively. The intra-assay CVs of TNF- $\alpha$ were between $3.7 \%$ (at 591 $\mathrm{pg} / \mathrm{ml}$ ) and $5.2 \%$ ( at $86.7 \mathrm{pg} / \mathrm{ml}$ ) and the inter-assay CVs were from $8.0 \%$ ( at 162 $\mathrm{pg} / \mathrm{ml}$ ) to $9.9 \%$ ( at $664 \mathrm{pg} / \mathrm{ml}$ ). While those of IL-6 were between $5.1 \%$ (at 38.8 $\mathrm{pg} / \mathrm{ml}$ ). and $7.7 \%$ ( at $242.7 \mathrm{pg} / \mathrm{ml}$ ), and $7.8 \%$ ( at $236.7 \mathrm{pg} / \mathrm{ml}$ ) to $9.3 \%$ (at 35.3 $\mathrm{pg} / \mathrm{ml}$ ), respectively.

Briefly, each specific monoclonal antibody against IL-18, TNF $-\alpha$, or IL-6 has been precoated onto a microplate. Standards and samples were pipetted into the wells. Any IL-18, TNF- $\alpha$, or IL-6 present reacted with capture monoclonal antibodies (MAbs-1) coated in the microtiter well. Then, MAb2, a horseradish peroxidase (HRP)- labelled second antibody was added in IL-18 and TNF- $\alpha$ ELISA kits while in IL-6 ELISA Kit, a biotinylated monoclonal second antibody was added followed by addition of streptavidin- peroxidase (enzyme ) which bound to the biotinylated antibody. Bound enzyme labelled antibodies were measured through a chromogenic reaction and the developed colour was in proportion to the cytokine concentration. The optical density (O.D.) of each well was then measured at $450 \mathrm{~nm}$ using a microplate reader. The concentration of each cytokine was determined from a dose response curve based on reference standards.

\section{Statistical methods:}

The obtained results were expressed as mean \pm standard deviation followed by Student t-test analysis. Correlations between 2 variables were estimated by Spearman's rank sum test. A p value less than 0.05 was considered statistically significant (Altman, 1994).

\section{Results}

The results of the current study are represented in tables 1 and 2 and figures 1 to 3 .

\section{Clinical and laboratory characteristics of patients:}

As shown in table 1, no stastically significant difference was found regarding age between the diabetic patients and control subjects. However, body mass index and fasting blood glucose in diabetic patients were significantly different than control subjects $(p<0.001)$. The patient group had higher FBG values and increased body mass index.

\section{Demographic profiles of diabetic patients according to urinary albumin excretion:}

According to urinary albumin excretion, diabetic patients were classified into 3 groups; normoalbuminuria i.e. below 30 $\mu \mathrm{g} / \mathrm{mg}$ creatinine included 22 patients, microalbuminuria between $30-300 \mu \mathrm{g} / \mathrm{mg}$ creatinine included 20 patients, and clinical albuminuria $>300 \mu \mathrm{g} / \mathrm{mg}$ creatinine included 8 patienes.

Table 2 compares the main clinical and laboratory features among these groups. No statistically significant differentces were found regarding age, BMI, FBG, $\mathrm{HbAlc}$, high density lipoprotien cholesterol (HDL-C) and CRP between patients with and without albuminuria. However, triglycerides (TG), total cholesterol (T-C) and creatinine levels $(\mathrm{Cr})$ were significantly different in patients with clinical albuminuria than those without albuminuria. The majority of patients with clinical albuminuria showed high TG, T-C and $\mathrm{Cr}$ values $(p<0.05)$. Moreover, $\mathrm{Cr}$ levels were significantly increased in patients with clinical albuminuria compared to those with microalbuminuria $(\mathrm{p}<0.05)$.

\section{Serum levels of (IL-18), (TNF- $\alpha$ ) and (IL-6):}

As shown in Table 1, serum levels of IL-18, TNF- $\alpha$, and IL-6 were significantly higher in the patients than control subjects $(p<0.001)$. Similar results were obtained 


\section{Interleukin -18 and other inflammatory cytokines}

when male and female patients were compared separately with the control subjects $(\mathrm{p}<0.001)$ (figure 1-3).

Macroangiopathy was found in 37 patients out of 50 (9 with old cerebral infarction, 20 with an old myocardial infarction, and 8 with atherosclerosis obliterans (ASO), who showed a statistically signifycant difference as regarding the serum levels of IL-18. The majority of diabetic patients with macroangiopathy had higher serum levels of IL-18 compared to those without it (IL-18, $336.0 \pm 25.7 \mathrm{pg} / \mathrm{ml} \mathrm{v}$ $276.1 \pm 13.2 \mathrm{pg} / \mathrm{ml}, \mathrm{p}<0.001)$. They also showed higher serum levels of TNF- $\alpha$ ( TNF- $\alpha, 77.6 \pm 10.2 \mathrm{pg} / \mathrm{ml}$ v $52.0 \pm 9.0$ $\mathrm{pg} / \mathrm{ml})$ but no statistically significant difference $(\mathrm{p}>0.05)$.

However, patients with macroangiopathy showed lower serum levels of IL-6 than those lacking it (IL-6, $96.5 \pm 14.2$ $\mathrm{pg} / \mathrm{ml}$ $116.5 \pm 15.3 \mathrm{pg} / \mathrm{ml}$ ) although this difference was not statistically signify-cant ( $>>0.05)$.

In addition, when patients with diabetes mellitus were divided into 3 groups according to the degree of albumin excretion (Table 2 ), serum IL-18 was significantly increased in the diabetic patients, even in those without microalbuminuria, when compared with the control subjects $(250.5 \pm 15.4 \mathrm{pg} / \mathrm{ml} \mathrm{v} 126.0 \pm$ $20.5 \mathrm{pg} / \mathrm{ml}, \mathrm{p}<0.001)$. Furthermore, patients with microalbuminuria or clinical albuminuria showed higher levels of serum IL- 18 than those with normoalbuminuria. However, no significant difference in IL-18 level was observed between patients with microalbuminuria and clinical albuminuria. Similar tendencies were observed when male and female diabetics with microalbuinuria were examined separately.

As regards serum TNF- $\alpha$ levels, diabetic patients showed higher values compared with control subjects, irrespective of the degree of albuminuria; however, patients with microalbuminuria showed significantly higher TNF- $\alpha$ levels than those without it (Table2) $(p<0.05)$. When male and female patients were Compared separately along with the controls, similar results were obtained.

As seen in Table 2, serum IL-6 increased in an almost linear fashion in accordance with the increase in urinary albumin excretion, and diabetic patients with clinical albuminuria had levels that were significantly increasd over those with and without microalbuminuria $(\mathrm{p}<0.05)$. Similar tendencies were observed in male and female diabetic patients.

Moreover, there were significant relationships between serum IL- 18 or TNF- $\alpha$ levels and FBG or HbAlc ( IL-18 v FBG, $r=0.260, p<0.001$; IL-18 v HbAlc, $\mathrm{r}=0.179, \mathrm{p}<0.05)($ TNF- $\alpha$ v FBG, $\mathrm{r}=$ 260, $\mathrm{p}<0.001$; TNF- $\alpha$ v HbAlc, $\mathrm{r}=180$, $\mathrm{p}<0.05$ ). In contrast, no such relationships were observed between serum levels of IL18 or TNF- $\alpha$ and age or CRP (data not shown). However, no significant relationships were found between serum IL-6 levels and age or other biochemical parameters such as FBG, Hb Alc and CRP (data not shown). 
Table 1: Serum levels of IL -18 , TNF $-\alpha$ and IL-6 along with demographic data of patients and control subjects.

\begin{tabular}{|l|c|c|c|c|c|c|c|c|c|}
\hline & \multicolumn{3}{|c|}{ Total } & \multicolumn{3}{c|}{ Male } & \multicolumn{3}{c|}{ Female } \\
\cline { 2 - 9 } & $\begin{array}{c}\text { DM } \\
(\mathrm{n}=50)\end{array}$ & $\begin{array}{c}\text { Control } \\
(\mathrm{n}=35)\end{array}$ & Pvalue & $\begin{array}{c}\text { DM } \\
(\mathrm{n}=27)\end{array}$ & $\begin{array}{c}\text { Control } \\
(\mathrm{n}=20)\end{array}$ & Pvalue & $\begin{array}{c}\text { DM } \\
(\mathrm{n}=23)\end{array}$ & $\begin{array}{c}\text { Control } \\
(\mathrm{n}=15)\end{array}$ & Pvalue \\
\hline Age(yr) & $53.2 \pm$ & $54.8 \pm$ & $\mathrm{NS}$ & $53.9 \pm$ & $55.0 \pm$ & NS & $52.5 \pm$ & $53.0 \pm$ & NS \\
& 1.0 & 0.8 & & 1.4 & 0.6 & & 1.2 & 1.1 & \\
$\mathrm{BMI}$ & $28.1 \pm$ & $24.3 \pm$ & $<0.001$ & $28.0 \pm$ & $22.4 \pm$ & $<0.001$ & $32.0 \pm$ & $24.2 \pm$ & $<0.001$ \\
$\left(\mathrm{~kg} / \mathrm{m}^{2}\right)$ & 2.6 & 3.6 & & 0.4 & 0.3 & & 1.2 & 2.6 & \\
$\mathrm{FBG}$ & $175.4 \pm$ & $95.5 \pm$ & $<0.001$ & $141.3 \pm$ & $98.2 \pm$ & $<0.001$ & $201.0 \pm$ & $91.5 \pm$ & $<0.001$ \\
$(\mathrm{mg} / \mathrm{dl})$ & 12.5 & 5.0 & & 10.8 & 5.2 & & 18.3 & 4.8 & \\
& & & & & & & & & \\
$\mathrm{HbA1c}(\%)$ & $8.2 \pm$ & $\mathrm{ND}$ & - & $8.5 \pm$ & $\mathrm{ND}$ & - & $8.2 \pm$ & $\mathrm{ND}$ & - \\
& 1.0 & & & 0.5 & & & 0.2 & & \\
$\mathrm{IL}-18$ & $282.0 \pm$ & $126.0 \pm$ & $<0.001$ & $300.5 \pm$ & $157.8 \pm$ & $<0.001$ & $270.8 \pm$ & $130.0 \pm$ & $<0.001$ \\
$(\mathrm{pg} / \mathrm{ml})$ & 12.5 & 20.5 & & 15.5 & 9.9 & & 14.0 & 11.5 & \\
$\mathrm{TNF}-\alpha$ & $75.0 \pm$ & $6.3 \pm$ & $<0.001$ & $85.0 \pm$ & $10.5 \pm$ & $<0.001$ & $65.0 \pm$ & $8.7 \pm$ & $<0.001$ \\
$(\mathrm{pg} / \mathrm{ml})$ & 14.8 & 2.9 & & 13.4 & 3.4 & & 13.5 & 2.4 & \\
IL-6 & $123.6 \pm$ & $10.6 \pm$ & $<0.001$ & $133.5 \pm$ & $14.0 \pm$ & $<0.001$ & $113.7 \pm$ & $8.5 \pm$ & $<0.001$ \\
$(\mathrm{pg} / \mathrm{ml})$ & 17.0 & 2.3 & & 12.0 & 4.0 & & 13.2 & 2.6 & \\
\hline
\end{tabular}

Abbreviations : DM, diabetes mellitus ; BMI, body mass index ; FBG, Fasting blood glucose ;

$\mathrm{HbA1c}$, hemoglobin A1c; ND, not determind; NS, not significant.

Table 2: Serum levels of IL-18, TNF - $\alpha$ and Il-6 along with demopraphic data for all diabetic patients according to urinary albumin excretion.

\begin{tabular}{|l|c|c|c|}
\hline & \multicolumn{3}{|c|}{ Uninary albumin excretion } \\
\hline & $\begin{array}{c}\text { Normoalbuminuria } \\
(\mathrm{n}=22)\end{array}$ & $\begin{array}{c}\text { Micoalbuminuria } \\
(\mathrm{n}=20)\end{array}$ & $\begin{array}{c}\text { Clinical albuminuria } \\
(\mathrm{n}=8)\end{array}$ \\
\hline Age $(\mathrm{yr})$ & $51.8 \pm 1.3$ & $53.7 \pm 2.4$ & $54.6 \pm 2.1$ \\
\hline BMI $\left(\mathrm{kg} / \mathrm{m}^{2}\right)$ & $28.7 \pm 0.3$ & $28.9 \pm 0.4$ & $29.2 \pm 0.7$ \\
\hline FBG $(\mathrm{mg} / \mathrm{dl})$ & $159.2 \pm 12.1$ & $170.0 \pm 14.0$ & $166.7 \pm 10.5$ \\
\hline HbA1c(\%) & $8.2 \pm 0.2$ & $8.5 \pm 0.3$ & $8.0 \pm 0.4$ \\
\hline TG(mg/dl) & $219.6 \pm 15.5$ & $229.2 \pm 14.6$ & $253.2 \pm 20.0^{*}$ \\
\hline T-C $(\mathrm{mg} / \mathrm{dl})$ & $210.9 \pm 6.8$ & $219.2 \pm 10.0$ & $240.6 \pm 21.2^{*}$ \\
\hline HDL-C & $30.5 \pm 3.5$ & $28.6 \pm 4.0$ & $28.9 \pm 2.0$ \\
\hline Cr(mg/dl) & $0.7 \pm 0.1$ & $1.3 \pm 0.5^{*}$ & $6.3 \pm 2.0^{*}+$ \\
\hline CRP(mg/dl) & $0.6 \pm 0.1$ & $0.5 \pm 0.1$ & $0.6 \pm 0.2$ \\
\hline IL-18(pg/ml) & $250.5 \pm 15.4$ & $362.8 \pm 14.2^{*}$ & $358.5 \pm 16.0^{*}$ \\
\hline TNF- $\alpha(\mathrm{pg} / \mathrm{ml})$ & $65.0 \pm 10.0$ & $118.2 \pm 14.1^{*}$ & $100.0 \pm 15.0$ \\
\hline IL-6 $(\mathrm{pg} / \mathrm{ml})$ & $80.0 \pm 12.2$ & $96.5 \pm 14.3$ & $188.8 \pm 17.6^{*}+$ \\
\hline
\end{tabular}

Abbreviations: TG, triglycerides, T-C, total cholesterol, HDL-C, high density lipoprotein cholesterol ; CRP, C- reactive protein; $\mathrm{Cr}$, Creatinine

$* \mathrm{P}<0.05 \mathrm{v}$ Normoalbuminuria

$+\mathrm{P}<0.05$ v microalbuminuria 
Interleukin -18 and other inflammatory cytokines

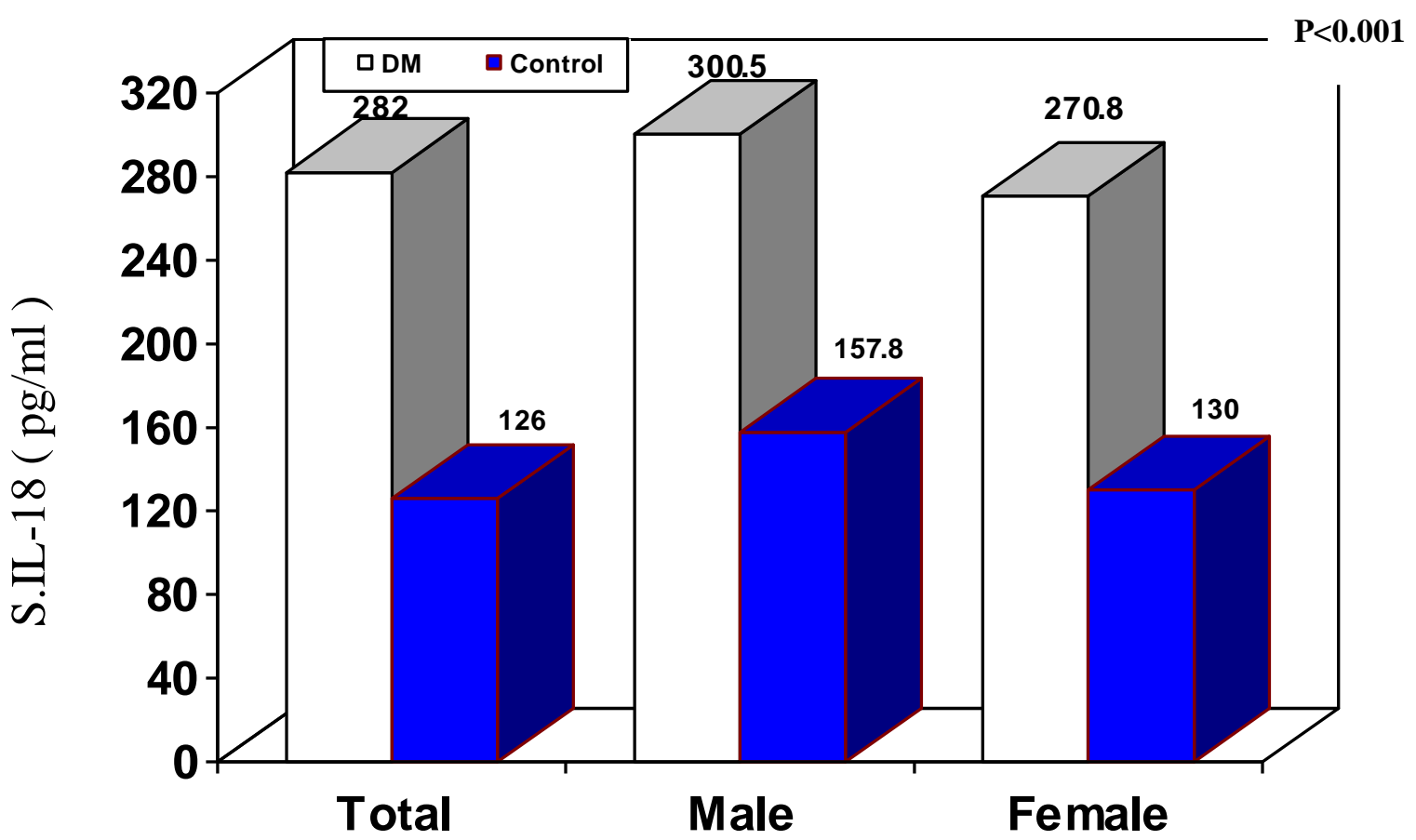

Figure 1 : Comparison of serum IL-18 levels between diabetic patients and control subjects.

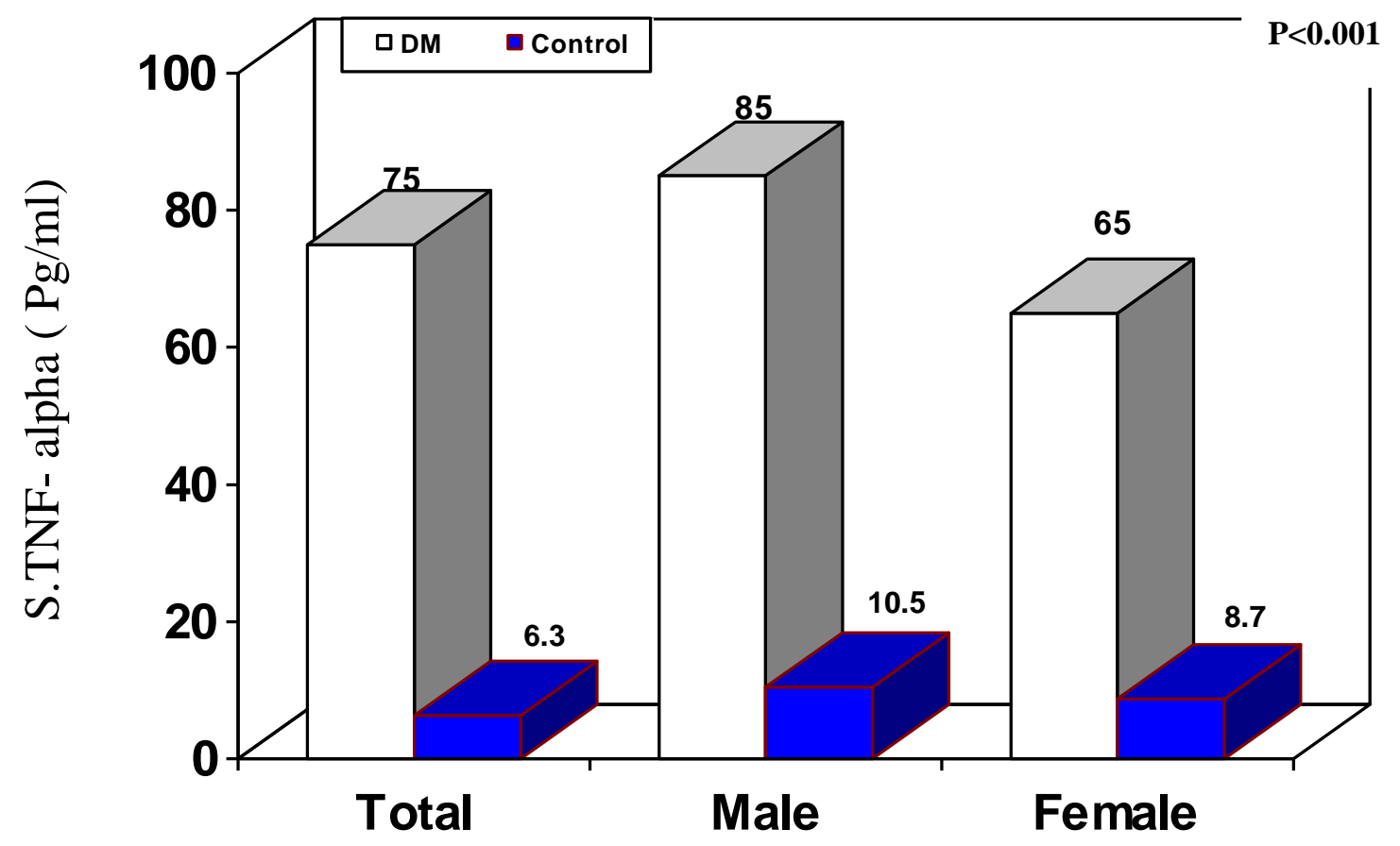

Figure 2: Comparison of serum TNF- $\alpha$ levels between diabetic patients and control subjects. 


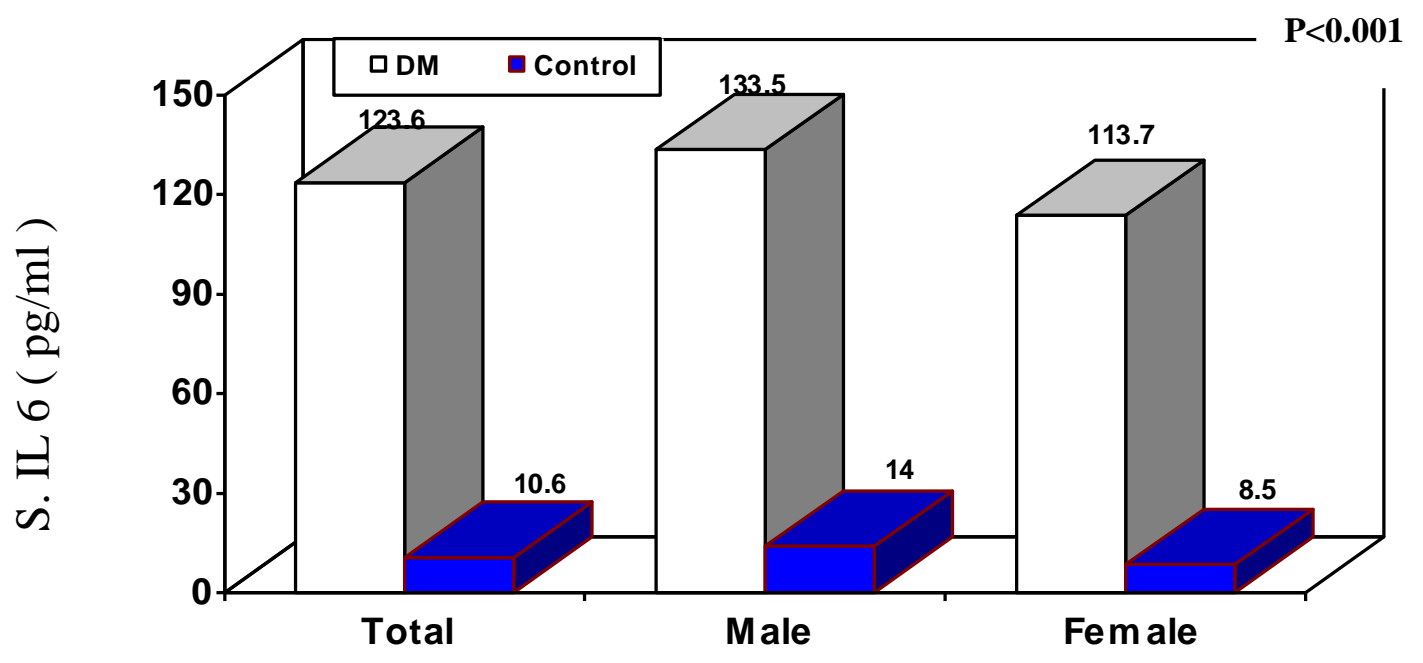

Figure 3: Comparison of serum IL-6 levels between diabetic patients and control subjects.

\section{Discussion}

There is spectrum of abnormalities in the kidneys of patients with type 2 diabetes mellitus. Hyperglycemia and advanced glycosylation products are various postulated mechanisms in the development of diabetic nephropathy (Brownlee, 1992 and Beisswengerm, 1994 ).

There are no previous detailed studies as regard IL-18 with type 2 diabetes mellitus. Very little is known about the relationship between diabetes mellitus type 2 and IL-18 except for some reports that have noted the possible involvement of IL18 with type 1 diabetes mellitus(Rothe et al., 1999 and Nicoletti et al., 2001).

In our study, there was a significant increase in the serum level of IL-18 in type 2 diabetes mellitus and this was in agreement with Moriwaki et al. (2003).

Previously, it was reported that IL-18 is constitutively expressed in renal tubular epithelia (Fantuzzi et al., 1999) as it has been reported to be increasingly released from tubular cells during ischemic acute renal failure (Melnikov et al., 2001 ) While Moriwaki et al. (2003) found the increased serum IL- 18 in type 2 diabetes mellitus and reported that it has been derived form the glomerular resident cells.

Thus it is probable that increased levels of IL-18 are also released from tubular cells in diabetic states and that the cytokine plays a deleterious role in diabetic nephropathy.
However, when considering the pathogenensis of diabetic nephropathy, the possibility of glomerular origin of IL-18 can't be fully excluded. It is well known that macrophages infiltrate the glomeruli and or interstitium in renal tissue in diabetic patients with nephropathy. Therefore, infilterating macrophages may be responsible for increased levels of IL-18 as the highest IL-18 levels were observed in patients with microalbuminuria, in contrast to those with clinical albuminuria, in whom the infilteration of macophages may be ceased (Moriwaki et al., 2003).

Our study revealed that there was significant increase in the serum level of TNF- $\alpha$ and IL- 6 in type 2 diabetes mellitus (Table1). These results were in concordance with the results obtained by katsuki et al. (1998) and Pickup et al. (2000) who found increased serum concentratian of IL- 6 and TNF- $\alpha$ in type 2 diabetes mellitus patients. Howewew, Moriwaki et al. (2003) found that IL-6 was not elevated in their patients but the underlying cause of these discrepancies remain unclear from their data.

Our study revealed no relationship between increased serum levels of IL-18 and TNF- $\alpha$ in patients with type 2 diabetes mellitus and CRP. This indicates that the increased serum levels of IL-18 and TNF- $\alpha$ in type 2 diabetes mellitus patients 


\section{Interleukin -18 and other inflammatory cytokines}

didn't reflect inflammation and this was in concordance with the study of Mariwaki et al. (2003).

Also, we found a statistically significant difference between the increased levels of IL-18 and TNF- $\alpha$ and the incidence of macroangiopathy $(\mathrm{p}<0.001)$. This indicates the role of cytokines ( $I L-18$ and TNF- $\alpha$ ) in the incidence of arteriosclerotic diseases.

In conclusion, the serum concentration of IL-18 in type 2 diabetes mellitus patients was slightly higher than non diabetic control subjects. in addition it was shown that serum TNF- $\alpha$ and IL-6 were also increased in the same patients. The levels of IL-18 and TNF- $\alpha$ in the serum were correlated with glycemic control as reflected by FBG and HbA1c. Serum IL-18 levels increased with the development of diabetic nephropathy. So it may have some etiopathogenic role in the development of diabetic nephropathy since it is increased with the presence of albuminuria as TNF- $\alpha$ and IL-6 . It may also reflect early diabetic nephropathy since increased levels were observed in diabatic patients without overt proteinuria.

\section{References}

1. Altman DG (1994): Practical statistics for medical research . Chia bled champion and Hall, London: P.218.

2. American Diabetes Association (1997): Report of the expert committee on the diagnosis and classification of diabetes mellitus. Diabetes Care, 20 : 1183-1201.

3. American Diabetes Association (1998): Diabetic nephropathy. Diabetes Care,21 : 550-553.

4. Beisswen Ger pj (1994) : Formation of immunochemical advanced glycosylation end products precedes and correlates with early manifestation of renal and retinal disease in diabetes. Diabetes, 44:824.

5. Bennatt JC (1996): Approach to the patient with immune diseases. Cecil Textbook of medicine, $20^{\text {th }}$ ed . Philadelphia, W.B. Saunders: P.1395.

6. Brownlee M (1992): Glycation products and pathogeneis of diabetic complication Diabetes Care, 15:1835.
7. Dipetrillo K, Coutermarsh B and Gesek FA (2003): Urinany tumor necrosis factor contributes to sodium retention and renal hypertrophy during diabetes. AJP-Renal physiology, 284: 113-121.

8. Fantuzzi G, Reed DA and Dinarello CA (1999): IL-12- induced IFN- gamma is dependent on caspase-1 processing of the IL-18 precursor. J Clin Invest, 104:761767.

9. Katsuki A, Sumida y and Mura shima $\mathbf{S}$ (1998): Serum levels of tumor necrosis factor- $\alpha$ are increased in obese patients with non insulin-dependent diabetes mellitus. J Clin Endocrinol Metab 83: 859 - 862.

10. Melnikov VY, Ecder $\mathbf{T}$ and Fantuzzi $\mathbf{G}$ (2001) : Impaired IL-18 processing protects caspase-1- deficient mice from ischemic acute renal failuse. J Clin Invest, 107: 1145- 1152.

11. Moriwaki Y, Yamamoto $\mathbf{T}$, and Schibututani Y (2003) : Elevated levels of interleukin - 18 and tumor necrosis factor $\alpha$ in serum of patients with type 2 diabetes mellitus: Relationship with diabe-tic nephropathy. Metabolism, 52 : 1-9.

12. Nicoletti F, Conget $\mathbf{I}$ and DiMrco $\mathbf{R}$ (2001) : Serum levels of the interferon $-\gamma$ inducing cytokine interleukin -18 are increased in individuals at high risk of developing type 1 diabetes. Diabetolgia, 44: 309-311.

13. Park E, Quinn MR, Wright CE and Schuller- levis G (1993): Taurine chloramine inhibits the synthesis of nitric oxide and the release of tumor necrosis factor in activated RAW 264.7 cells. J leucocyte Biol, 54: 119-124.

14. Pickup JC, chusney GD, Thomas SM (2000): Plasma interleukin -6 , tumor necrosis factor- $\alpha$ and blood cytokine production in type 2 diabetes. Life Sci, 67: 291-300.

15. Remuzzi G, Schieppati A and Ruggenenti P (2002): Nephropathy in patients with type 2 diabetes. New England J Medicine, 346: 1145-1151.

16. Rothe $\mathbf{H}$, Jenkins $\mathbf{N}$ and Copelond $\mathbf{N}$ (1999): Active stage of autoimmune diabetes is associated with the expression of a novel cytokine, IGIF, which is located near 1 dd 2 .J Clin Invest, 99:469-474.

17. Timothy C, Evans MD, and Peter Capell (2000) : Diabetic nephropathy MD. Clinical Diabetes, 18:1

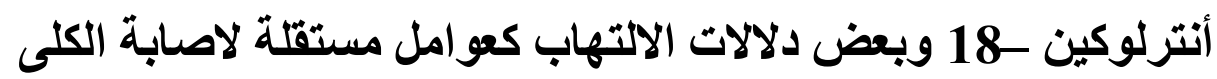




\section{فى مرضى السكر النوع الثانى}

\section{سحر محمود شوقى** و إيمان عبد الرحمن اسماعيل

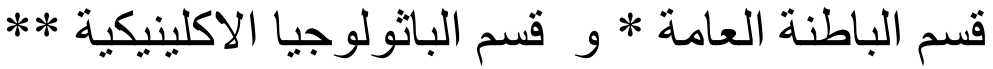 كلية الطب - جامعة عين شمس}

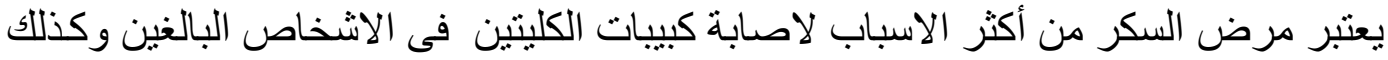

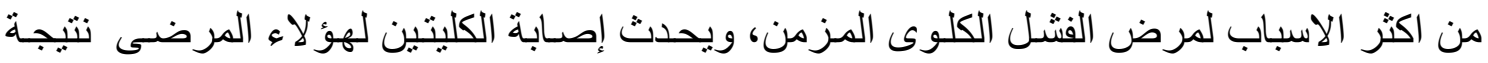

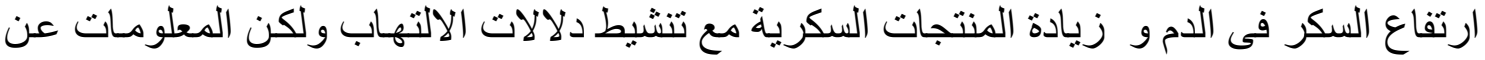
السبب الاخير قليلة وتحتاج للار استة.

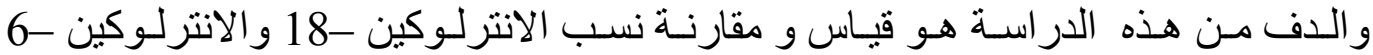

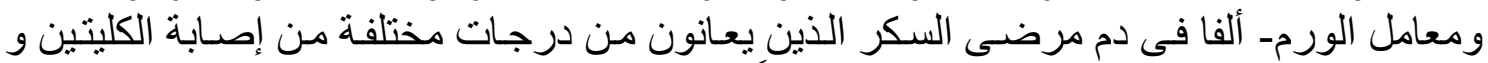

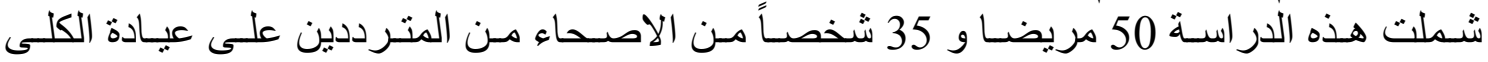

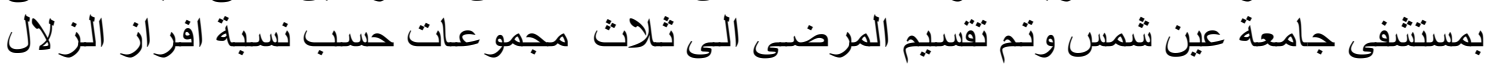
بالبول الى :• مجمو عة 1 وتشمل 22 مريضـاً حيث نسبة افراز الز لال بـالبول اقل من 30ميكرجر ام / مللى جر ام كرياتينين. • مجموعـة 2 وتشـمل 20 مريض حينـ نسبة افراز الز لال بـالبول مـن 30- 300 ميكرجرام / مللى جر ام كرياتينين. • مجموعة 3 وتشمل 8 مريضاً حيث نسبة افر از الز لال بالبول اكثر من 300 ميكرجرام / مللى جر ام كرياتينين.

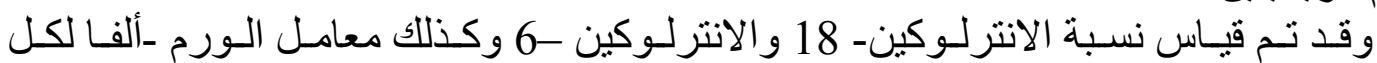

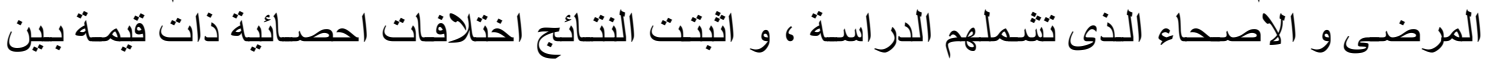

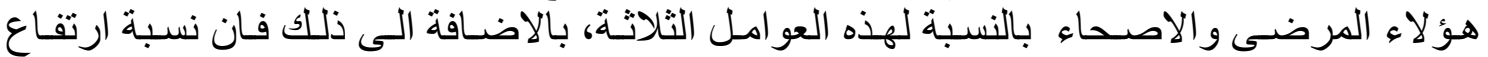

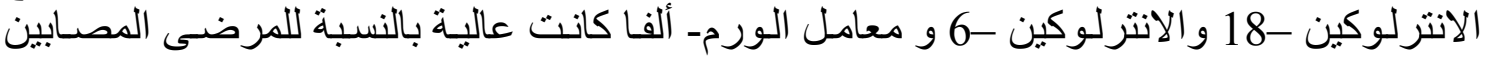

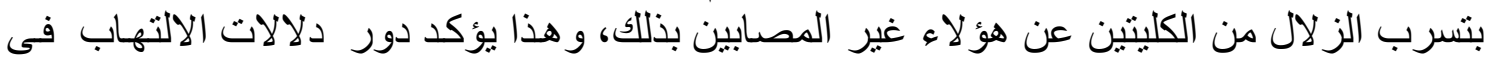

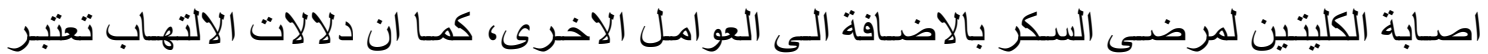

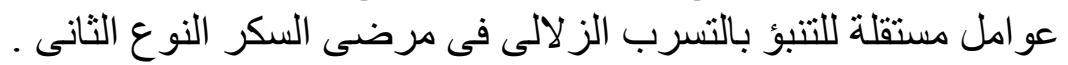

